\title{
Socialist Internationalism and Decolonizing Moralities in the UN Anti-Trafficking Regime, 1947-1954
}

\begin{abstract}
In the late 1940s, state socialist governments proclaimed that commercial sex did not exist under socialism. At the same time, they were enthusiastic participants in the drafting of a new UN Convention for the Suppression of the Traffic in Persons and the Exploitation of the Prostitution of Others. This article explores state socialist involvement in the global moral reform drive accompanying the 1949 Convention. It traces the ideological coherence between Socialist Bloc and 'western' delegations on the desirability of prostitution's abolition. Conversely, it highlights cleavages on issues of jurisdiction, manifesting in the Soviet call for the eradication of the draft Convention's 'colonial clause', which allowed states to adhere to or withdraw from international instruments on behalf of 'non-self-governing territories'. We argue that critiques of the colonial clause discursively stitched together global moral reform and opposition to imperialism, according socialist and newly-decolonized delegations an ideological win in the early Cold War.
\end{abstract}

On 11 August 1954, the Union of Soviet Socialist Republics acceded to the 1949 UN Convention on the Suppression of the Traffic in Persons and the Exploitation of the Prostitution of Others (1949 UN Convention), which had opened for signature at Lake Success on 21 March 1950. ${ }^{1}$ The USSR, whose delegation to the UN Economic and Social Council (ECOSOC) had firmly supported the Convention in its draft stages, prefaced its accession with the declaration that: 'In the Soviet Union the social conditions which give rise to the offences covered by the convention have been eliminated'. ${ }^{2}$ In characteristic double-speak, the USSR's accession simultaneously supported the Convention and the international legal attempt to suppress prostitution globally, and denied that the social problems addressed by the Convention existed in areas under its

\footnotetext{
${ }^{1}$ United Nations, Treaty Series, (Vol. 96, 1951), 271.

${ }^{2}$ Declarations and Reservations to the Convention for the Suppression of the Traffic in Persons and of the Exploitation of Others, Lake Success, New York, 21 March 1950,' in UN, Treaty Series, (Vol. 96, 1951), 349. This declaration was also expressed by the delegations of Ukraine and Belarus. The Convention and accompanying Soviet reservations were published in the USSR in Ministerstvo Inostrannykh Del SSSR, Sbornik deistvuiushchikh dogovorov, soglashenii i konventsii, zakliuchennykh SSSR s inostrannymi gosudarstvami. Vypusk XVI. (Moscow: Gosudarstvennoe Izadatel'stvo Politicheskoi Literatury, 1957), 280-290.
} 
jurisdiction. Embedded within this claim was the implicit assertion of the moral superiority of Soviet-style socialism, which had supposedly eradicated social 'problems' including commercial sex. By evoking a selfless commitment to the international importance of eradicating prostitution, the Soviet delegation positioned itself as the vanguard of social reform at a global scale.

Socialist countries in Eastern Europe played a crucial role in successfully shaping and passing the 1949 UN Convention. In the evolving taxonomies of international law, the 1949 Convention fell somewhere between pre-1945 conceptualisations of international criminal law (ICL) and international humanitarian law (IHL), best described as international law targeting transnational crime. ${ }^{3}$ Later Soviet commentators would refer to this category as 'crimes of an international nature', to differentiate from state-driven atrocities. ${ }^{4}$ The Convention's home in the ECOSOC also highlighted the perceived humanitarian or social welfare exigencies of suppressing 'the exploitation of the prostitution of others'. But why was this Convention important to the Soviet Union and its Eastern European allies if it purportedly addressed a problem which did not exist in areas under their own jurisdiction? What may it tell us about the Convention - and about the ways both prostitution and the traffic in persons were conceptualised in the post-war world - that the eventual form and content bore their imprint? And what can we glean about the specificities of state socialist approaches to international law from this case study?

This article answers these questions by first examining the Convention's genealogy and the history of its genesis in the late 1940s. It then considers the ways in which socialist understandings of prostitution, its causes and potential 'solutions', were embedded within the responses of the Soviet, Ukrainian and Czechoslovak delegations. Finally, the article turns to the little-known history of the Soviet delegation's successful effort to remove the colonial clause

\footnotetext{
${ }^{3}$ On the dialogic relationship between conceptualisations of 'international' and 'transnational' crime in a Soviet context see Hetherington, Philippa. 'The Highest Guardian of the Child: International Criminology and the Russian Fight Against Transnational Obscenity, 1885-1925'. Russian History 43(3-4) (2016), 275-310.

4 Esakov, Gennady. 'International Criminal Law and Russia: From Nuremberg Passion to The Hague Prejudice'. Europe-Asia Studies (69.8, 2017), 1188; Karpets, I. I., Prestupleniia mezhdunarodnogo kharaktera (Moscow: Iuridicheskaia Literature, 1979), 31-53; Karpets discusses 'trafficking in women' specifically at 173-177, criticising the 1949 Convention for focusing on prostitution to the detriment of a specific clause on trafficking for prostitution.
} 
from the Convention and in so doing to claim a moral victory on behalf of socialism and antiimperialism against capitalism. Examining the discussions on the Convention, the article focuses in particular on the Soviet approach, with reference to the differing position of fellow socialist state, Czechoslovakia.

We argue that the negotiations around the 1949 Convention were marked by ideological tensions, but these did not focus on the social desirability of suppressing prostitution, about which there was remarkable agreement. Rather, the Soviet Union and its allies saw the enforcement elements of the Convention as the key source of political contention between socialist and western states. Focusing on these, socialist delegates as well as delegates from recently decolonized states put questions of sovereignty and jurisdiction at the heart of an ostensibly uncontroversial social policy debate. This was particularly evident in the debates over the inclusion of the so-called colonial clause, which allowed imperial powers to decide whether or not the convention would extend to colonies, rather than guaranteeing automatic application to them. After Soviet and recently decolonized delegates successfully argued for the colonial clause's deletion, both France and Great Britain voted against the Convention and refused to ratify it. ${ }^{5}$ For the Soviet delegates, the oppressive or liberatory potential of the Convention resided less in substantive policy questions regarding the best way to end prostitution, about which they largely agreed with the 'capitalist' delegations, and more in the extent it which it did or did not advance an anti-imperial cause. ${ }^{6}$ In highlighting these dynamics, our approach follows recent scholars in arguing that socialist states took international law 'seriously', despite the classical Marxist position that it was just a tool of the oppressing classes. ${ }^{7}$ Their behaviour at the

\footnotetext{
${ }^{5}$ For recent work on international law and empire, see Koskenniemi, Martti, Walter Rech, and Manuel Jimenez Fonseca (eds), International Law and Empire. Historical Explorations (Oxford: Oxford University Press 2017). ${ }^{6}$ It goes without saying that Soviet rhetorical opposition to imperialism did not include any self-reflection on Moscow's own, arguably imperial, relationship to Eastern Europe, Central Asia, or the Caucasus.

${ }^{7}$ Amos, Jennifer. 'Embracing and Contesting: The Soviet Union and the Universal Declaration of Human Rights, 1948-1958'. In Human Rights in the Twentieth Century, ed. Stefan Ludwig Hoffmann, (Cambridge: Cambridge University Press 2010), 147-165; Hirsch, Francine. 'The Soviets at Nuremberg: International Law, Propaganda and the Making of the Postwar Order,' American Historical Review 113(3) (2008), 704-705; Bowring, Bill. Law, Rights and Ideology: Landmarks in the Destiny of a Great Power (New York: Routledge, 2013), 77-96; Malksoo, Lauri, Russian Approaches to International Law. (Oxford: Oxford University Press, 2015) 42-71; Betts, Paul. 'Socialism, Social Rights and Human Rights: The Case of East Germany'. Humanity 3(3) (2012), 407-426; Richardson-Little, Ned. 'Between Dictatorship and Dissent: Ideology, Legitimacy and Human Rights in East Germany, 1945-1990,' (PhD Dissertation, University of North Carolina, 2013).
} 
United Nations was not merely an effort to disrupt western nations' foreign policy aims, but also an effort to forge an alternative way of using and viewing the international legal system.

\section{A Genealogy of Law against Human Trafficking for Prostitution}

The 1949 UN Convention was the fifth in a series of international anti-trafficking agreements that began with the 1904 International Agreement for the Suppression of the 'White Slave Traffic'. ${ }^{8}$ This agreement was signed by, among others, the Russian Empire, France and the UK and it addressed trafficking as a problem of cross-border recruitment and 'procuring' of minors for prostitution. It explicitly refrained from any discussion of national legislation on prostitution within a state's borders. ${ }^{9}$ This agreement, and a later 1910 Convention extending it, were then taken up in the interwar period by the League of Nations' Traffic in Women and Children Committee, in which prostitution-regulationist states such as France held significant sway. The language of two League of Nations conventions from 1921 and 1933 continued to focus only on the transnational recruitment and transportation of women for prostitution purposes, albeit they raised (1921) and then eliminated the age limit (1933) at which it was considered women could consent to sex work abroad. They also introduced calls for more intensive surveillance of borders and migrant sex workers than those invoked by the earlier 1904 and 1910 agreements. ${ }^{10}$ The League's anti-trafficking initiatives were a key pillar of what was known as the Social Section that unit of the League dedicated to formulating international agreements to address 'social

\footnotetext{
${ }^{8}$ There is a rich literature on the emergence of the white slave panic in Western Europe and North America at the fin-de-siècle; see especially Camiscioli, Elisa. Reproducing the French Race: Immigration, Intimacy and Embodiment in the Early Twentieth Century (Durham: Duke University Press 2006); Chaumont, Jean-Michel. Le mythe de la traite des blanches. Enquête sur la fabrication d'un fléau (Paris: La Découverte 2009); Donovan, Brian. White Slave Crusades: Race, Gender and Anti-Vice Activism, 1887-1917 (Urbana-Champaign: University of Illinois Press 2006); Guy, Donna. Sex and Danger in Buenos Aires: Prostitution, Family and Nation in Argentina (Lincoln: University of Nebraska Press 1991); Limoncelli, Stephanie. The Politics of Trafficking: The First International Movement to Combat the Sexual Exploitation of Women (Stanford: Stanford University Press 2010); Walkowitz, Judith R..City of Dreadful Delight: Narratives of Sexual Danger in Late Victorian London (Chicago: University of Chicago Press 1992).

${ }^{9}$ On the 1904 agreement and the 1910 convention see Allain, Jean. 'White Slave Traffic in International Law'. Journal of Trafficking and Human Exploitation 1 (2017), 1-40.

${ }^{10}$ On the League's 1921 'International Convention for the Suppression of the Traffic in Women and Children' and 1933 'International Convention for the Suppression of the Traffic in Women of the Full Age 'see Legg, Stephen. "“The Life of Individuals as well as of Nations": International Law and the League of Nations' Anti-Trafficking Governmentalities'. Leiden Journal of International Law 25 (2012), 647-664; Pliley, Jessica. 'Claims to Protection: The Rise and Fall of Feminist Abolitionism in the League of Nations' Committee on the Traffic in Women and Children, 1919-1936'. Journal of Women's History 22(4) (2010), 90-113; Tambe, Ashwini. 'Climate, Race Science and the Age of Consent in the League of Nations'. Theory, Culture and Society, 28 (2001), 109-130.
} 
problems' as part of the broader efforts to buttress world peace. ${ }^{11}$ Of particular relevance was the negotiation between 1930 and 1937 of the so-called Draft Convention for Suppressing the Exploitation of the Prostitution of Others (1937 Draft Convention), which was finalized in 1937, but never officially adopted due to the war.

In the postwar United Nations, the issue of 'social questions' was taken up by the ECOSOC. ${ }^{12}$ On March 29th 1947, ECOSOC adopted Resolution 43 (IV) on Social Questions, which included - among other things - a section on the Suppression of the Traffic in Women and Children. ${ }^{13}$ The resolution instructed the Secretary-General to transfer the 'functions formerly exercised by the League of Nations' to the UN as well as to reassess and amend the 1937 Draft Convention before submitting it to governments and subsequently to the ECOSOC for approval. Thus, when the UN section of 'Social Defense' started working on the new draft, it did not start from scratch. ${ }^{14}$

The overall process leading to the final version of the 1949 UN Convention can be subdivided into three phases. ${ }^{15}$ The first phase started before 1945 and can be found in the origins of the 1937 Draft Convention on which the UN's Social Defense section based its new draft. Since 1930, the League's Legal Sub-Committee of the Advisory Committee on Traffic in Women and Children had been discussing the institutionalization of the offense of 'pimping' as an international crime. ${ }^{16}$ These efforts formed part of a broader push to unify criminal law that had been gaining pace within the League since the late 1920s. ${ }^{17}$ Specifically, the Sub-Committee

\footnotetext{
${ }^{11}$ On the League's social programs see Rodríguez García, Magaly, Davide Rodogno, and Liat Kozma. The League of Nations' Work on Social Issues: Visions, Endeavours and Experiments (Geneva: United Nations Publications, 2016); Rodríguez García, Magaly. 'La Société des Nations face à la traite des femmes et au travail sexuel à l'échelle mondiale'. Le Mouvement Social 4 (2012), 105-125.

${ }^{12}$ On background to the founding of the ECOSOC and its Social Commission see Milhaud, Maurice. 'Social Commission'. World Affairs 110(4) (1947), 245-251.

${ }^{13}$ United Nations, Economic and Social Council, ECOSOC Resolution 43 (IV) on Social Questions, document E/437, March 29th 1947.

${ }^{14}$ Jakobi, Anja P. Common Goods and Evils: The Formation of Global Crime Governance (New York: Oxford University Press 2013), 70-71.

15 A full legal and historical account of the complex and lengthy process of negotiating the 1937 Draft Convention or the $1949 \mathrm{UN}$ Convention has yet to be written and is beyond the scope of this paper.

${ }^{16}$ Legal Subcommittee, CTFE/CJ 1930-1936, CTFE/CJ/2 ${ }^{\text {nd }}$ session/PV 1933, CTFE/CS 1935-1936. Research on the Legal Sub-Committee is still rare. For a general overview see Rodríguez García, Magaly. 'The League of Nations and the Moral Recruitment of Women'. International Review of Social History 57 (2012), 97-128, 113-119.

${ }^{17}$ See Lewis, Mark. The Birth of the New Justice: The Internationalization of Crime and Punishment, 1919-1950 (Oxford: Oxford University Press 2014). From 1933, the advice of the International Association for the Unification of Penal and its Secretary General, Vespasian Pella, would be offered to the Sub-Committee. Vespasian Pella later
} 
aimed at eradicating both the traffic in women and prostitution itself by explicitly targeting thirdparties and intermediaries in the sex trade: the so-called souteneurs. ${ }^{18}$ However, reaching a common definition of the crime was no easy task. By 1937, the working parties agreed on the formula of the 'exploitation of the prostitution of others' to capture the crime committed by whomever:

in order to gratify the passions of another and for the purposes of gain, procures, entices or leads away by whatever means, even with their consent, a person of either sex of full age for the purpose of exploiting that person's prostitution. ${ }^{19}$

The 1937 Draft Convention was the starting point of the new UN 1949 Convention. The negotiation process at the United Nations took nearly three years and included a number of ECOSOC Resolutions and two drafts from the section of Social Defense in cooperation with the department of Legal Affairs. ${ }^{20}$ During a first, non-public phase (1947-1948), member states as well as NGOs with consultative status were invited to offer comments on both drafts. It was only after this that the second draft was discussed in what may be described as a limited international public sphere in the Social Commission (May 1949), the ECOSOC (July 1949), the Third and Sixth Committee of the General Assembly, and the Plenary Session of the General Assembly in last quarter of 1949. It was during these sessions that the state socialist members of the UN attempted to mould the convention at the level of both form and content.

Beside the internationalization of the individual crime of 'pimping', the second nonpublic phase saw the successful introduction of a regulation-abolitionist approach to prostitution into the convention. When the UN Convention was circulated to member states in September 1947, its stated goal was to follow the 1937 Draft in widening the scope of previous agreements to include the 'protection of persons of full age of either sex against being exploited for immoral

\footnotetext{
became a delegate to the Legal Sub-Committee for Romania, and after 1945 to the 'Social Defence' section at the UN. League of Nations Archives, Social Section, Sub-Section on Traffic in Women and Children, Box R. 4664.

${ }^{18}$ Preliminary Draft International Convention of the punishment of persons who live on the immoral earnings of women, League of Nations Archives, CTFE/CJ/1.

${ }^{19}$ United Nations, Division of Social Activities, Draft Convention of 1937 for Suppressing the Exploitation of the Prostitution of Others. Memorandum by the Secretary-General, E/574, UN Archives New York, Branch Registries, Volume III - Convention for the Suppression of Traffic in Persons and Obscene Publications, Box S-0441-1163, File 218/03/03, Art. 1, 6.

20 The Social Defense section was led by Polish-British criminologist Leon Radzinowicz, who reflected on the experience in his memoir Adventures in Criminology, 380-387.
} 
purposes by a third party, even with their consent and even without being taken abroad' (emphasis ours). ${ }^{21}$ Compared to the conventions of 1904, 1910, 1921 and 1933, the new text greatly expanded its reach into the national domain by requiring governments to repeal the regulation of prostitution and to create a criminal law framework targeting third parties. Beyond these criminal law provisions, the first draft targeted prostitutes themselves. Even though a direct criminalization of selling of sex was never explicitly on the table, article 4 of the first draft criminalized prostitutes soliciting in public. The comment to this article somewhat sheepishly acknowledged the contradictions between the punitive and rehabilitative aims of the Convention. It stated that while 'the draft convention does not intend to make the act or prostitution itself a punishable offense...it seems desirable to protect society, especially young persons, against accosting in the streets and other public places'. ${ }^{22}$

The proposed UN Convention also evinced a notably carceral approach to the 'social welfare' of women selling sex. Article 17(2) of the first draft specified that 'a specialized social service' should 'communicate to the Secretary-General of the United Nations information concerning effective methods which are used or contemplated for the social treatment of individual prostitutes or persons living on the verge of prostitution'. ${ }^{23}$ This article was followed by an unusually long comment laying out preventive, protective and rehabilitative measures, including some with a coercive character. ${ }^{24}$ According to the vision of the Social Defense section, these rehabilitative measures were to be embedded in a system of doctors, psychiatrists, social workers and 'women police'. This approach fit with the 'social defense' take on crime with its focus on the protection of society through the prevention of individual deviancy. ${ }^{25}$ According to the later Chief of the section, Manuel Lopez-Rey, the focus on the prevention of individual crime targeted 'habitual crime', which included prostitution and 'related matters' ${ }^{26}$ Against this backdrop, the legal and social status of the prostitute remained contested. She or he

\footnotetext{
${ }^{21}$ United Nations, Draft Convention of 1937, E/574.

22 Ibid., 8-9.

23 Ibid., 15.

24 Ibid.

${ }^{25}$ Delierneux, Adolphe. 'The United Nations in the Field of Prevention of Crime and Treatment of Offenders'. In Current approaches to delinquency: Yearbook 1949, ed. National Probation and Parole Association (New York, 1949), 248-258.

${ }^{26}$ Lopez-Rey, Manuel. 'First U. N. Congress on the Prevention of Crime and the Treatment of Offenders. Journal of Criminal Law and Criminology 47(5) (1957), 526-538.
} 
was framed as both victim and potential agent of deviance against which society needed to be protected.

While some elements of the first UN draft betrayed a carceral vision of the path to ending prostitution, other aspects were more grounded in the philanthropic and social reform genealogy of international approaches to prostitution since the nineteenth century. Article 14 mandated that signatory states provide 'free medical care for venereal diseases (VD) insofar as their national resources permit'. ${ }^{27}$ The guarantee of free medical care addressed both the general public health issue of preventing VD in the wake of the mandated abolition of regulated prostitution and the need for prostitutes' 'physical rehabilitation'. According to the abolitionist framework, the treatment of VD was supposed to be provided free of charge and confidentially, guaranteeing both the protection of public health and the rights of prostitutes or persons with VD.

The first draft reveals the extent to which 'trafficking', always conceptualised as a crime at the intersection of forced migration and forced prostitution, had become a category through which prostitution could be debated more broadly in the post-war period. Throughout the 1930s and the 1940s the 'solutions' proposed to trafficking had gradually shifted away from regulating transnational migration, which had dominated the discussion since the 1890s, to the suppression of commercial sex in general. While the substance and norms of a global approach to domestic prostitution laws were still contested, all delegations at the UN spoke with remarkable uniformity on their shared condemnation of prostitution as a manifestation of undesirable sexuality and undesirable labour.

\section{Socialist States Confront the Convention for the International Suppression of Prostitution}

At first, the Convention did not garner the interest of many governments; of the 57 UN member states only 15 replied to the first draft with suggestions and amendments, which were circulated in November 1948. ${ }^{28}$ The newly-socialist state of Czechoslovakia, whose communist government had been installed after a coup in February 1948, was one of the few that did. The

\footnotetext{
${ }^{27}$ United Nations, Draft Convention of 1937, E/574.

${ }^{28}$ United Nations, Economic and Social Council, Observations submitted by Governments and Non-Governmental Organizations with respect to the revision of the 1937 Draft Convention Suppressing the Exploitation of the Prostitution of Others, E/1072/Annex 2, November 18th 1948.
} 
first draft was deemed 'acceptable', because it 'conforms, for the most part, with the Czechoslovak regulations'. ${ }^{29}$ Comments on single provisions were limited to article 12 concerning international police cooperation. The Czechoslovak government favoured the creation of so-called 'criminal centres', which would directly communicate with each other in the 'international fight for the suppression of crime'. ${ }^{30}$ This was not a new idea; indeed, in the interwar period much of the League of Nations' Traffic in Women Committee's energies had been devoted to calls for greater cooperation between police forces within signatory states to the 1921 and 1933 Conventions. ${ }^{31}$ The International Criminal Police Commission (renamed Interpol in 1956) had played an increasingly prominent role in League discussions from the 1930s, sitting on the League Sub-Committee tasked with drafting what would become the 1937 Draft Convention from 1935. ${ }^{32}$ Thus, when the Czechoslovak Government argued that the convention 'should express the principle of cooperation between the United Nations and the International Criminal Police Commission', it was laying a claim for a continuation of a carceral approach to the suppression of prostitution promoted by the international community since the interwar period. ${ }^{33}$ On the question of specific conformity with Czechoslovak law the delegation remained silent. Perhaps this was because the Czechoslovak position was itself in flux at the time; it was not until 1950 that the communist government would produce its first socialist penal code, which criminalized pimping and brothel-keeping. Prostitution would, however, not be criminalized directly, but come to be classed as a form of 'parasitism' in a 1956 amendment to the code. ${ }^{34}$

Other respondents to the 1947 draft were less reticent on substantive legal issues, and controversy soon arose over the question of relative culpability of those involved in the sex trade,

\footnotetext{
${ }^{29}$ United Nations, Observations, E/1072/Annex 2, 2.

${ }^{30}$ Ibid., 37.

${ }^{31}$ Deflem, Mathieu. Policing World Society: Historical Foundations of International Police Cooperation (Oxford: Oxford University Press, 2002) 82. For some of the 'on-the-ground' implications of these calls for police cooperation see Petruccelli, David. 'Pimps, Prostitutes and Policewomen: The Polish Women Police and the International Campaign Against the Traffic in Women and Children between the World Wars'. Contemporary European History 24(3) (2015), 333-350.

${ }^{32}$ League of Nations, Traffic in Women and Children. Report of the Work of its Fourteenth Session (Geneva) 21 May 1935, C.227.1935.IV, p.3. On the International Criminal Police Commission Petruccelli, David. 'Banknotes from the Underground: Counterfeiting and the International Order in Interwar Europe'. Journal of Contemporary History 51(3) (2016), 507-530.

${ }^{33}$ United Nations, Observations, E/1072/Annex 2, 37.

${ }^{34}$ Havelková, Barbara. 'Blaming all Women: On Regulation of Prostitution in State Socialist Czechoslovakia'. Oxford Legal Studies 36(1) (2016), 165-191, 171. The citation for the 1950 Czech Criminal Code is Act. No86/1950 Coll, and the 1956 amendment is Act No 63/1956 Coll, s.188a.
} 
especially the question of the social and legal status of the prostitute within international law. At heart was the following: who should be penalised, the prostitute or the intermediaries (pimps, procurers and brothel owners)? Over the course of the nineteenth and early twentieth centuries, increasingly influential abolitionist voices had argued that prostitutes themselves should not be blamed or punished for the 'crime' of prostitution. ${ }^{35}$ However, the first draft proposed both the criminalization of third party involvement in prostitution and of solicitation for commercial sex by individuals. ${ }^{36}$ It was not a surprise that non-governmental organisations, such as the International Abolitionist Federation, expressed outrage at this draft, given the risk that women selling sex could be punished for keeping a brothel or soliciting. ${ }^{37}$ These NGOs ensured that the negative implications for prostitutes in the first draft were duly noted by the UN Secretariat. ${ }^{38}$

In the light of the comments by both governments and NGOs, the Social Defense section drafted a revised second draft, whose reach was broadened to explicitly incorporate the provisions of all the previous anti-trafficking agreements, while abandoning the punishment of solicitation. ${ }^{39}$ Just before the revised second draft was discussed in the Social Commission in May 1949, new observations by the Czechoslovak government signed by the Czech government's chief UN representative, Dr. Vladimir Houdek, were sent to the Secretariat. ${ }^{40} \mathrm{He}$ took issue with the abandonment of soliciting as a crime, arguing that the newer 'provisions [...]

\footnotetext{
${ }^{35}$ Laite, Julia. 'The Association for Moral and Social Hygiene: abolitionism and prostitution law in Britain (19151959)'. Women's History Review 17(2) (2008), 207-223; or a comparative study on the abolition of regulated prostitution in France, Germany and Italy, see König, Malte. Der Staat als Zuhälter. Die Abschaffung der reglementierten Prostitution in Deutschland, Frankreich und Italien im 20. Jahrhunderts (Berlin/Boston: Walter De Gruyter 2016) on abolitionism see also Walkowitz, Judith R. Prostitution and Victorian Society. Women, class and the state (Cambridge: Cambridge University Press 1980), 90-147.

${ }^{36}$ United Nations, Draft Convention of 1937, E/574, 8.

${ }^{37}$ United Nations, Observations, E/1072/Annex 2, 21-22. The exact wording of Article 2 presented in draft E/574 was: 'Each of the High Contracting Parties further agrees to declare all houses or places of prostitution to be public nuisances and to provide for the punishment of any person who keeps or manages a building or place or a part thereof for the purpose of prostitution or being the owner thereof knowingly rents the said building or place or a part thereof for that purpose. / It shall be a punishable offense to finance or take part in the financing of a house or place of prostitution." United Nations, Draft Convention of 1937, 8.

${ }^{38}$ United Nations, Draft Convention of 1937, E/574, 14-15; United Nations, Observations, E/1072/Annex 2, 45. Our interpretation of the NGOs' position is based not only on E/1072/Annex 2, but also on the bulk of archival records on NGOs feedback to the first draft. See UN Archives New York, Volume III, Box S-0441-1163.

${ }^{39}$ The second draft was finalized in document E/1072, which also became the working draft in the Fourth Session of the Social Commission in May 1949 and was first circulated in December 1948, see: United Nations, Economic and Social Council, Draft Convention for the Suppression of the Traffic in Persons and of the Exploitation of the Prostitution of Others, E/1072, December 23rd 1948.

40 On Houdek's appointment to the UN immediately after the 1948 coup in Czechoslovakia see 'Czech Coup Before Council', United Nations News: Report on the United Nations and Its Related Agencies (New York: Woodrow Wilson Foundation, 1948), 25.
} 
do not quite tally with the regulation of Czechoslovak penal legislation' ${ }^{41}$ Houdek's comment helped to clarify the Czechoslovak delegation's understanding of the Convention, which he thought should indeed target prostitution per se. In line with socialist thought, he argued that efforts to prevent prostitution should focus on the improvement of socio-economic conditions. ${ }^{42}$ However, he also called for 'repressive' means to end prostitution, which included 'enrolment for labour and re-education of women prostitutes' as well as 'curative treatment' conducted 'simultaneously with the fight against VD (a principle embedded within his support for compulsory treatment of disease). ${ }^{43}$ Houdek defended 'the principle of compulsory treatment of VD', which he saw as the 'responsibility of the individual toward the whole community' and opposed the regulation-abolitionist idea of free, voluntary and confidential treatment as 'gratis treatment of VD'. ${ }^{44}$ This position, however, remained a rare instance of socialist support for a practice associated with prostitution regulation. More in line with the usual socialist antipathy to regulation was the response of the Soviet delegate during one of the sessions of the Social Commission in May 1949. Echoing abolitionism, the Soviet representative Aleksandr Borisov stressed how 'free treatment of VD' was necessary and 'constituted an important stage in the rehabilitation of prostitutes'. His amendment to introduce free services was, however, rejected. ${ }^{45}$

Contrary to later claims that prostitution did not exist in Czechoslovakia, the focus on repressive measures as well as on international police cooperation in criminal matters points to the fact that prostitution or trafficking were not perceived to be gone from one day to the next. As Barbara Havelková has recently argued, prostitution policy in early state socialist Czechoslovakia, while surrounded by a discourse of class struggle, largely continued the abolitionist position that had been pursued during the interwar years. The language of 'enrolment for labour' presaged a shift that was concretized in the new 1956 Czechoslovak penal code towards classifying prostitution as a form of work shirking and thus 'parasitism', whereby

\footnotetext{
${ }^{41}$ United Nations, Division of Social Activities, 'Letter by Dr. Vladimír Houdek, Permanent Delegation of Czechoslovakia to the United Nations, to Trygve Lie,' May 6th 1949, UN Archives New York, Volume III, Box S0441-1163, File 218/04/01.

${ }^{42}$ United Nations, Letter from Houdek to Lie.

${ }^{43}$ Ibid.

${ }^{44}$ Ibid.

${ }^{45}$ United Nations, Economic and Social Council, Social Commission, Fourth Session, Summary Record of the Seventy-Fourth Meeting, May 5th 1949, E/CN.5/Sr 74, 14.
} 
prostitutes were to be condemned for failing to take their places as productive members of Czechoslovak society. ${ }^{46}$

In contrast to Houdek's tacit acknowledgment that there was still the need for a 'struggle against prostitution', by 1949 the Soviet Union was claiming that the problem of prostitution and, by implication, the traffic in persons, had been successfully abolished in the Soviet Bloc. The claim that prostitution had been 'eradicated' in the USSR had been the official position of the Soviet state since the early 1930s, when the supposed achievement of full female employment was meant to have removed any economic incentive to selling sex. ${ }^{47}$ This claim was predicated on the long history of Marxist interpretations of prostitution, which framed commercial sex as a response to economic deprivation. According to this interpretation, elaborated in the nineteenth century by Engels and August Bebel and in the early twentieth by Clara Zetkin and Aleksandra Kollontai, women in prostitution were victims of economic and social oppression and could only be 'saved' by a socialist revolution. ${ }^{48}$ At the same time, soon after the Bolshevik revolution figures such as Kollontai began to talk uneasily of the threat of prostitution as a form of work shirking, decrying those women who continued to sell sex even when offered the option of 'productive labour' by the state. 'And what', Kollontai asked rhetorically, 'is the professional prostitute? She is a person whose energy is not used for the collective; a person who lives off others, by taking from the rations of others' ${ }^{49}$ With the declaration of the First Five Year Plan in 1928, the narrow space available to frame prostitutes as victims of capitalism disappeared. The NKVD, which had been quietly rounding up women as 'professional prostitutes' and sending them to labour camps since 1924, began to include them in mass sweeps of 'socially harmful elements'. ${ }^{50}$ Women selling sex fell into the millions-strong category of victims of Stalinist terror.

\footnotetext{
${ }^{46}$ Havelková, 'Blaming all the Women,' 171.

${ }^{47}$ On attempts to reform Soviet prostitutes through labour see Bernstein, Frances. 'Prostitutes and Proletarians: The Soviet Labor Clinic as Revolutionary Laboratory'. In The Human Tradition in Modern Russia, ed. William Husband (Wilmington: Scholarly Resources Inc, 2000).

${ }^{48}$ Classic articulations include Engels, Friedrich. The Origin of the Family, Private Property and the State (London: Penguin, 2010, originally 1884); Bebel, August. Women and Socialism (New York: Socialist Literature Co., 1910, originally 1879); Zetkin, Clara. Die Arbeiterinnen und Frauenfrage der Gegenwart (Berlin: Berliner Bolts-Tribüne, 1889); Kollontai, Aleksandra. Sotsial'nie osnovy zhenskogo voprosa, (St Petersburg: Znanie, 1909).

${ }^{49}$ Kollontai, Aleksandra. 'Prostitution and Ways of Fighting it'. In Alix Holt, Selected Writings of Alexandra Kollontai (Allison and Busny, 1977). Originally published in 1921.

${ }^{50}$ On prostitutes as 'social parasites' and 'socially harmful elements see Gosudarstvennyi Arkhiv Rossiiskoi Federatsii, hereafter GARF, Fond r-393, Opis' 1a, Delo 202, 1926, 'Rezoliutsii soveshchaniia Narodnykh
} 
Thus, when the Soviet delegate to the Third Committee of the 1949 General Assembly, Vasilii Zonov, asserted that 'better social and working conditions had long eradicated prostitution from his country', he was articulating a claim on the international stage that had been made domestically for two decades. ${ }^{51}$ This stance largely excluded the Soviet delegation from debates about substantive issues and practical questions about how to deal with third parties, infrastructure (brothels) and prostitutes. There were, however, a few exceptions to the Soviet lack of engagement into matters of substance. For example, at various point during the negotiation of article 1 and its definition of the 'exploitation of the prostitution of others' ('pimping'), the long-standing definitional controversy arose again over whether the goal of profiting from someone else's sexual labour ('motives of gain') was the defining element of this crime. While the British position was that a simple encouragement or mediation of prostitution should not be liable to punishment, but only profiting from such encouragement, a number of NGOs, ranging from women's and religious organisations to the International Criminal Police Organization, opposed the retention of the 'purpose of gain' in article 1, as did the Unites States and all socialist countries. The reasons they offered were not just based on legal considerations but also ideas about civilizational progress that was supposedly inherent in the condemnation and criminalization of prostitution. In particular, delegates argued that criminal law should indeed target morally reprehensible behaviour. In his contribution during the 263rd plenary meeting of the General Assembly, the Soviet Delegate, Aleksandr Paniushkin supported the deletion of 'motives of gain' based on the moral condemnation of all parties involved in prostitution, including the prostitute as, he argued, 'prostitution was a profession incompatible with the elementary principles of morality and a crime offensive to public decency'. ${ }^{52}$ The discussion of article 1 reveals a conception of the role of criminal law that would go beyond the

\footnotetext{
Komissarov Vnutrennikh Del Soiznykh i Avtonomnykh respublikh o bor'be s sotsial'nym paratsitizmam, strukture i metodakh raboty organov NKVD v tsentre i na mestakh i vzaimootnosheniiakh s drugimi vedomstvami i dr,' 1l. 33(ob) (Rezoliutsiia o bor'be s sotsial'nym parazitizmom); GARF f. A390, op. 21, d. 1, 'Narkomtrud, Komissiia po izucheniiu i ulucheniiu zhenskogo truda: Materialy o bor'be s prostitutsiei,'1923-1928, 11. 52-53.

${ }^{51}$ United Nations, General Assembly, Fourth Session 1949, Official Records, Third Committee (Social, Humanitarian and Cultural), 242nd Meeting, October 5th 1949, 40.

52 United Nations, General Assembly, Fourth Session 1949, Official Records, 263rd plenary meeting, December 2nd 1949, 461-462.
} 
criminalization of exploitative practices. It was intended to police sexual behaviour that was considered to be morally and socially reprehensible (such as the act of selling sex). ${ }^{53}$

In their condemnation not just of trafficking, but of prostitution itself, a variety of governments involved in the drafting of the 1949 UN Convention found a common political ground in a world that was increasingly divided. While the Cold War conflict became visible in assertions of countries such as the Soviet Union that prostitution did not exist on their territory because they had abolished the social conditions (poverty and unemployment) causing it, these conflict lines were neutralized in the shared critique of prostitution. This critique was framed in moral terms across the political spectrum, and bolstered (rather than challenged) a shift in the focus of opprobrium from prostitution to prostitutes in the Soviet Union, United States, and France. This Cold War consensus was all the more remarkable given the ultimate unworkability of the document the delegates produced. The near-global abolition of state-regulated prostitution during the twentieth century and especially after 1949 did not make prostitution, nor human trafficking disappear. Instead, the social organization of commercial sex slowly adapted itself to conditions of increasing criminalization. The persistence of paid sex thus elicited a myriad of localized state and social reactions ranging from highly repressive approaches to limited toleration combined with informal strategies of spatial segregation, but also, since the 1970s, increased opposition against abolition, especially by prostitutes' rights groups. ${ }^{54}$

\section{Consensus Breaks Down: The Debate over the Colonial Clause}

Despite disputes over the clauses such as that concerning the compulsory treatment for VD or the 'motives of gain' wording, delegations across the emerging Cold War divide shared a moralistic commitment to eradicating prostitution, through carceral measures directed at prostitutes if necessary. Turning to issues of enforcement and jurisdiction surrounding the Convention, however, we can trace major cleavages between the socialist and newly decolonized states on the one hand, and the former imperial powers (and their allies) on the other. In these debates, socialist and newly--decolonized delegations successfully connected the moral condemnation of

\footnotetext{
53 United Nations, General Assembly, Fourth Session 1949, Official Records, Sixth Committee, 205th Meeting, November 25th 1949, 428-429.

54 Pheterson, Gail. A Vindication of the Rights of Whores: International Struggle for Prostitutes Rights (Seattle, WA: Seal Press, 1989).
} 
prostitution to a moral condemnation of colonialism, conceptually linking sexual deviance and the evils of empire. Analysis of the 1949 UN Convention reveals that the issue of jurisdiction was a key lever for the cultivation of a 'socialist approach' to international law.

At heart was the issue of the Convention's enforceability and its applicability (or not) to non-self-governing territories. Initially, the Soviet delegation was closely involved in discussions on whether matters relating to the Convention should be settled in the International Court of Justice or by arbitration, as well as questions relating to extradition or international police cooperation. ${ }^{55}$ Discussions of these aspects paled in comparison, however, to the extensive discussion on the issue of the so-called colonial clauses. All the pre-war international antitrafficking instruments contained articles that allowed a party state to sign on for, or exclude, any or all of its colonies - a so-called colonial clause. ${ }^{56}$ By the post-World War II period, critics contended that such clauses 'advanced the proposition that colonial territories were not valid, independent actors, and that in international law their existence was solely a function of the colonial relationship'. ${ }^{57}$ This was articulated in the context of a broader push to make colonial powers accountable for the development of self-government in territories under their control from the early days of the UN. Chapter XI of the UN Charter dealt with non-self-governing territories, with Article 73 committing administering Powers 'to ensure, with due respect for the culture of the peoples concerned, their political, economic, social, and educational advancement' as well as 'to take due account of the political aspirations of the peoples, and to assist them in the progressive development of their free political institutions'. ${ }^{58}$ From the outset, delegations from recently decolonised states in Africa and Asia were vociferous in their insistence on international

\footnotetext{
${ }^{55}$ The Soviet Union was long an opponent of including clauses on the arbitration of cases in the ICJ, a position it only abandoned with Perestroika in 1989; see Schweisfurth, Theodor. 'The Acceptance by the Soviet Union of the Compulsory Jurisdiction of the ICJ for Six Human Rights Conventions,' European Journal of International Law 10 (1990), 110-117.

${ }^{56}$ There is little scholarship on the colonial clauses, despite their importance to nineteenth and early twentieth century treaties including the 1904 International Agreement and 1910 Convention. The British government reserved the right to adhere to or withdraw from the anti-trafficking agreements on the part of its colonies from the very first (1904) agreement, as correspondence between the Home Office and the Foreign Office attests; see The National Archives (TNA), FO 83/2199, 16 May 1904 Landsdowne to Monson. See also Article II of the International Convention for the Suppression of the White Slave Traffic (1910).

${ }^{57}$ Roberts, Christopher N.J. The Contentious History of the International Bill of Human Rights, (New York: Cambridge University Press 2014), 130.

${ }^{58}$ For Article 73 of the UN Charter see http://www.un.org/en/sections/un-charter/un-charter-full-text/, last accessed 10 July 2018.
} 
accountability to ensure that colonial powers be held to these responsibilities. ${ }^{59}$ In the rapidly changing context of the post-war world, their efforts ensured that questions of self-determination were embedded in the very foundation of the post-war international legal regime, setting the stage for the first debates over the colonial clauses.

Colonial clauses were not confined to the anti-trafficking treaties - they were also present in the League anti-narcotics agreements and in the Genocide Convention, among other instruments. ${ }^{60}$ But it was the case of the anti-trafficking treaties which gave the Soviet delegation the first opportunity to announce its staunch opposition to such clauses and thus to the international legal approach of colonial powers. In October 1947, the Soviet delegation successfully proposed a resolution to the Third Committee of the UN's General Assembly calling on it to delete all colonial clauses as part of the adoption of the anti-trafficking treaties by the UN. ${ }^{61}$ Predictably, the British delegation made a counter-move, calling for an amendment to reinsert these provisions. ${ }^{62}$ In the immediate post-war period, Britain's Colonial Office remained insistent on the presence of colonial clauses, claiming that these provisions facilitated the consolidation of local autonomy in non-self-governing territories (to use the UN's preferred term for colonial territories). ${ }^{63}$ Former British colonies in the General Assembly, however, fervently and loudly disagreed, expressing support for the original Soviet resolution. Mr. Pirzada, the delegate for the (very) newly-independent Pakistan, declaring that 'if this amendment is passed, it will provide a loophole for the reactionary elements in the colonies' ${ }^{64}$ Furthermore, Pirzada asserted that any attempt to retain colonial clauses would undermine the very universal claims of the UN project more broadly, as by allowing imperial powers to pick and choose the colonies to which UN conventions applied they had the potential to exclude some subjects from the

\footnotetext{
${ }^{59}$ See El-Ayouty, Yassin. The United Nations and Decolonization: The Role of Afro-Asia (The Hague: Martinus Nijhoff, 1971), especially 29-66 'The Declaration Regarding Non-Self-Governing Territories and the Concepts of International Responsibility for Colonial Administration'.

${ }^{60}$ See Article XII of the Convention on the Prevention and Punishment of the Crime of Genocide (1948) and Article 8 of the Protocol Bringing Under International Control Drugs Outside the Scope of the Convention of 13 July 1931 for Limiting the Manufacture and Regulating the Distribution of Narcotic Drugs (1946). Domestic Soviet commentary on the Genocide Convention highlighted critique of the colonial clause; see Volodin, S, 'Konventsiia o preduprezhdenii prestupleniia genotsida i nakazanii za nego', Sovetskoe Gousdarstvo i Pravo (7, 1954), 125-128. ${ }^{61}$ United Nations General Assembly, Ninety-Seventh Plenary Meeting, Second General Assembly, 20 October 1947, 351.

${ }^{62}$ Ninety-Seventh Plenary Meeting, 354.

${ }^{63}$ Simpson, A.W. Brian. Human Rights and the End of Empire: Britain and the Genesis of the European Convention, (Oxford: Oxford University Press 2011), 288-289.

${ }^{64}$ Ninety-Seventh Plenary Meeting, 354
} 
protections supposedly offered by international law. ${ }^{65}$ In the light of opposition from both Socialist Bloc and recently decolonized states, the British amendment was rejected by the General Assembly, thus setting the scene for the decisive refusal of colonial clauses by the United Nations a year later when the revivified anti-trafficking Convention came up for discussion. ${ }^{66}$

By the end of 1948, the second draft Convention for the Suppression of Traffic in Persons was open for commentary in the ECOSOC's Social Commission. In the fourth session of the commission in May 1949, the Soviet representative, Aleksandr Borisov, registered objections to multiple proposed amendments, including British attempt to remove the words 'for the purposes of gain' from the definition of pimping and a French attempt to allow for (limited) state regulation of prostitution. ${ }^{67}$ But most important for the Soviets at this point was their opposition to the continued inclusion of the colonial clause (Article 27). Such a clause, Borisov declared, 'might lead to the uncontrolled expansion of the traffic in persons and the exploitation of prostitution in the very territories most predisposed thereto'. as trafficking (he implied) was more likely to occur in the oppressed colonies, which had been denied the social and economic progress experienced by the metropole. ${ }^{68}$ Mobilising a discourse of cultural developmentalism, Borisov suggested that imperialism had imposed a moral backwardness on colonies that the 1949 Convention promised to rectify. In this way, he discursively linked the post-war language of global moral reform to the critique of empire, in language that would prove influential in the coming debates about the Convention's final form.

The United Kingdom and France opposed this argument, arguing that in fact the colonial clauses allowed them to consult with their non-self governing territories, to give them the option to accede or not to the convention even when they did not have self-government. ${ }^{69}$ However, the Soviet delegations stood their ground, ensuring that the issue of the colonial clause would come

\footnotetext{
${ }^{65}$ Ninety-Seventh Plenary Meeting, 354.

${ }^{66}$ United Nations, Resolution of the General Assembly, U.N. Doc. A/519. 1947, 32-39; Ninety-Seventh Plenary Meeting, 355.

${ }^{67}$ UN Economic and Social Council, Report of the Fourth Session of the Social Commission to the Economic and Social Council, E/1359; E/CN.5/152, 31 May 1949, 5- 7

${ }^{68}$ UN Economic and Social Council, Report of the Fourth Session of the Social Commission to the Economic and Social Council, E/1359; E/CN.5/152, 31 May 1949, 7.

${ }^{69}$ UN Economic and Social Council, Report of the Fourth Session of the Social Commission to the Economic and Social Council, E/1359; E/CN.5/152, 31 May 1949, 8.
} 
up in the Third Committee's discussions about the draft text before the Convention came before the General Assembly. The Soviet intervention highlights the extent to which it perceived the 1949 UN Convention as having an humanitarian aim (despite the fact that it was technically framed within an inchoate body of transnational criminal law). In their representation, a colonial clause opened the door to a refusal of colonial powers to extend social benefits to the colonies.

The debates over the colonial clauses, and the tussle between the United Kingdom and France on the one side, and the Soviet and decolonized bloc on the other, came to a head at the 264th Plenary Meeting of the General Assembly in December 1949, which was tasked with finalizing the Convention's text. In the final meeting of the Third Committee prior to putting the draft convention before the General Assembly, the delegate of the Ukrainian SSR put forward an amendment that declared that, in the wording of the Convention, 'The word State shall include all the colonies and Trust Territories of a State signatory acceding to the convention, and all Territories for which such State in internationally responsible' ${ }^{70}$ Thus the goal was not only to remove the offending Article 27, but to ensure that imperial states signed on behalf of non-self governing territories in relation to every article in the Convention. This amendment could not but raise the ire of said imperial states, especially the United Kingdom. The subsequent discussion in the General Assembly on 2 December 1949 opened with a declaration by UK delegate Gerard Corley-Smith, who announced his country's staunch opposition to this amendment. In doing so, he deplored the positions of 'delegations such as those of the Ukrainian SSR and Poland, who had tried to infer in the Third Committee that the United Kingdom was a totalitarian, imperialistic Power, which kept its colonial territories in subjugations and which did not wish to apply to convention to its territories because it had no desire to improve social standards in those territories'. ${ }^{71}$ Suggesting that the Socialist Bloc had not only tried to interfere with but also to

\footnotetext{
${ }^{70}$ UN Economic and Social Council, Fourth Session. Third Committee, Item 62. Draft Convention for the Suppression of the Traffic in Persons and of the Exploitation of the Prostitution of Others. Ukrainian Soviet Social Republic Amendments to Articles 23, 24 and 27. A/C.3/L.10, 30 September 1949. It is important to note that the status of the delegations of both the Ukrainian SSR and Belorussian SSR were different to that of the other Socialist Bloc countries, as both were federative unites of the USSR but nonetheless had their own foreign ministries and own delegations. On the 'flexible' concept of sovereignty in the Soviet Union and the effect of this concept on the relationship between Soviet delegations at the UN see Dullin, Sabine and Etienne Forestier-Peyrat. 'Flexible Sovereignties of the Revolutionary State: Soviet Republics Enter World Politics'. Journal of the History of International Law 19 (2017), 178-199.

${ }^{71}$ United Nations General Assembly, Two-Hundred and Sixty-Fourth Plenary Meeting, Fourth General Assembly, A/PV.264, 2 December 1949, 467.
} 
smear the UK, Corley-Smith stated categorically that were the General Assembly to approve a version of the Convention without the colonial clause, the UK could not accede to it. ${ }^{72}$

Labelling the UK hypocritical, the Pakistani delegate, Ahmed Shah Bokhari, mobilized the language of morality to link the 'moral crime' of prostitution with the immorality of colonialism, declaring that 'so long as the metropolitan Powers clung to those vast congregations of peoples and to those vast territories, to which they had no moral right even though they might be trying in their own way to do good, all their actions would be full of contradictions and difficulties'. ${ }^{73}$ The removal of the colonial clause was a way to highlight the fundamental incompatibility of colonialism and the progressive social policies of the UN, as typified, in Bokhari's view, by the attack on trafficking and prostitution.

As the author of the key amendment removing the colonial clause, the Ukrainian delegate pronounced wearily that colonial powers clearly 'did not intend to combat seriously that social evil which was incompatible with the dignity of the human person', and were only 'taking refuge in legal quibbles' because they would like the traffic in persons to continue in their colonies. ${ }^{74}$ By speaking simultaneously of the immorality of colonialism and the moral fight against prostitution, the socialist and decolonized delegates suggested that the anti-colonial fight relied upon the moral uplift of colonies and their populations, and that the fight against prostitution was a key part of this struggle. That they did so in language which set aside claims for legal autonomy in favour of calls for the extension of international social programs, speaks to the evolving nature of socialist and anti-colonial activism in the context of the new United Nations, and of the post-war international legal landscape.

In the end, in December 1949 the postcolonial and Socialist Bloc argument won the day. The Ukrainian amendment was carried and entered the final text of the Convention, thus ensuring that it applied automatically to all constituent parts of a signatory state, and none could be excluded from it. When the ECOSOC produced a final convention draft for the General Assembly to vote on in 1949 , it lacked any colonial applicability clause. ${ }^{75}$ When the time came to vote on the text during the fourth General Assembly on December 2, the issue of colonial

\footnotetext{
72 A/PV.264, 468.

${ }^{73}$ A/PV.264, 470.

${ }^{74}$ A/PV.264, 469.

${ }^{75}$ A/PV.264, 472.
} 
clauses contributed to the decision of Britain and France to vote 'No' (the only 'No' votes) and of the United States to abstain. The USSR, Belorussian and Ukrainian delegations, alongside former colonial possessions including Burma, Cuba, Egypt, India, Iraq, Pakistan, and Syria and fellow state socialist delegations such as Czechoslovakia and Poland, contributed to the resounding 'Yes' vote. ${ }^{76}$

The October 1947 and December 1949 attacks on the colonial clause, spearheaded by the Soviet and Ukrainian delegations, preceded those which have been noted by historians as part of the 1947-1950 debates over the Universal Declaration on Human Rights and the International Covenant on Human Rights; indeed they arguably provided the template for the later controversy. ${ }^{77}$ In December 1947, two months after the initial discussion of the colonial clause and the 1949 Convention, the Soviet Union argued in the second session of the Commission on Human Rights that 'colonial dependencies should be explicitly included as beneficiaries of any human rights document' ${ }^{78}$ The issue of deleting the colonial clause also came up with regards to the drafting of the 1946 Protocol amending the 1931 Narcotics Convention as well as the 1948 UN Genocide Convention, although without success. ${ }^{79}$ The Soviet and post-colonial bloc's deletion of the colonial clause in the 1949 Convention was thus the first of its kind in the postwar era. It prompted what Christopher Roberts called the UN's subsequent 'bright-line rule' on colonial clauses, that in the absence of a colonial clause any convention would automatically 'apply to all territories for which the Contracting States had international responsibility'. ${ }^{80}$ Just as Hartley Shawcross, the British representative at the October 1947 meeting of the General Assembly, fearfully prophesied, the deletion of the colonial clauses from the 1949 UN Convention was used to bolster the anti-colonial position in later multilateral treaties concerning cross-border crime or human rights. ${ }^{81}$ Later, during the drafting of the International Covenants

\footnotetext{
${ }^{76}$ Ultimately, 35 member states voted Yes, two voted no, while there were 15 abstentions. Voting Record for UN Resolution A/Res/317(IV), December 2 1949, via United Nations Bibliographic Information System Voting Record Search, http://unbisnet.un.org:8080/ipac20/ipac.jsp?profile=voting\&menu=search. It is worth noting that France later signed on to the Convention in 1960; Britain and the United States never signed.

${ }^{77}$ Burke, Roland. Decolonization and the Evolution of International Human Rights (Philadelphia: University of Pennsylvania Press, 2010), 40-41.

${ }^{78}$ Roberts, The Contentious History, 128.

${ }^{79}$ See Letter from Mr Alan Renouf in the Legal Department to Mr Finn K. Tennfjord of the Social Activities Division, July 5 1949, in UN-NY, File No: LEG 2184/4/01, C/38/9/12/47.

${ }^{80}$ Roberts, The Contentious History, 130. Interestingly, while Roberts notes these discussions, he does not note their embeddedness within debates about the Convention on the Suppression of the Traffic.

${ }^{81}$ Ninety-Seventh Plenary Meeting, Second General Assembly, 20 October 1947, 351.
} 
on Human Rights, the Soviet Union clashed again with Great Britain over exactly this issue, with the latter attempting to insert a clause allowing it to exclude colonies from the Covenants. ${ }^{82}$ In the 1950 General Assembly, representatives of newly independent states including India and Syria excoriated the British position (which was supported by France and the US) and praised that of the USSR. ${ }^{83}$ In the end, the colonial clauses were definitively defeated, heralding the dawn of the anti-colonial bloc within the United Nations.

\section{Conclusion}

As this article has shown, a closer look at the negotiations of the 1949 UN Convention reveals contested and often contradictory ideas about the goals of this instrument and the ways they were to be achieved. Tensions initially emerged with regard to the status of the prostitute in societies without regulated prostitution, including socialist countries. Based on the assumption that both prostitution and the prostitute had disappeared with the introduction of socialism, the socialist stance on prostitution created a double-bind. As a non-existent problem, it could not be publicly discussed or debated without questioning the ideological pillars of the socialist stance on prostitution, and, possibly, socialism itself.

By shifting focus to the colonial clauses, the Soviet delegation was able to turn the apparently uncontroversial goal of protecting women from forced prostitution into a major ideological win for the socialist and anti-colonial camp at the UN. What is more, by pointing out that in the Soviet Union and many of the former colonies that stood with it, prostitution was criminalized or 'liquidated', the Soviet delegates were able to forge a discursive link between the moral outrage against colonialism, and the moral outrage against prostitution and trafficking in women. ${ }^{84}$ That they were able to do this despite a broad agreement across the emerging Cold War divides about the general immorality and criminality of prostitution speaks to evolving political and legal strategies within the UN. Faced with agreement on substantive issues, the Soviet delegations turned to questions of enforceability, and in particular questions of sovereignty and statehood in the applicability of international law. With these issues, they found

\footnotetext{
${ }^{82}$ Roberts, The Contentious History.

${ }^{83}$ Roberts, The Contentious History, 146, 149.

84 The liquidation of prostitution in Egypt was, for example, a key claim made by the Egyptian delegate at the aforementioned 2 December 1949 meeting of the General Assembly. A/PV.264, 468.
} 
a wedge with which to open up a (tense) debate on colonialism, decolonization, and the rights of non-self-governing territories.

The existing historiography on the Soviet Union, decolonization and the Cold War at the United Nations largely presents the debates on colonialism as a development that emerged under Nikita Khrushchev, tied to the shift to the Third World within the Soviet Union itself. ${ }^{85}$ As our analysis of the 1949 UN Convention deliberations shows, however, the Soviet delegation at the UN saw international law as a forum through which to critique imperialism, and to foster alliances against western states, as early as 1947. This was a period in which Soviet diplomats and jurists were experiencing a 'mania' for international law, in the wake of their key role the Nuremberg trials and involvement in the UN's International Law Commission. ${ }^{86}$ Their engagement with the form and substance of the 1949 Convention was thus not merely an attempt to obstruct for the sake of obstruction (as similar involvement in the Genocide Convention has been rather tendentiously framed by one historian). ${ }^{87}$ Instead, it represented an effort to use international law to propose an alternative vision of the new global political system, just as the British, French and US delegates did.

The 1949 UN Convention has often been misunderstood by both legal scholars and activists as a human rights document. ${ }^{88}$ Rather than human rights, however, this article has shown that a concern with the internationalization of criminal law and the creation of a global approach to commercial sex was the driving force behind the convention. Further, it was not questions of content alone that determined the debates surrounding the Convention or the decision by, for example, Britain to not ratify it. Arguments about jurisdiction, in particular regarding the colonial clauses, were entangled with the birth pangs of the UN, and the newly decolonized world. The 1949 UN Convention was embedded in the particular historical moment

\footnotetext{
${ }^{85}$ On the Soviet role in discussions about decolonization at the UN under Khrushchev see Gaiduk, Ilya. Divided Together: The United States, the Soviet Union, and the United Nations, 1945-1965 (Stanford: Stanford University Press, 2013), Iandolo, Alessandro. 'Beyond the Shoe: Rethinking Khrushchev at the Fifteenth Session of the United Nations General Assembly. Diplomatic History, 41(1) (2017), 128-154.

${ }^{86}$ Hirsch, 'The Soviets at Nuremberg'. See also Francine Hirsch's forthcoming book Soviet Judgment at Nuremberg: A Cold War Story.

${ }^{87}$ See Weiss-Wendt, Anton. The Soviet Union and the Gutting of the UN Genocide Convention (Madison: University of Wisconsin Press, 2017).

${ }^{88}$ See for example Reanda, Laura, 'Prostitition as a Human Rights Question: Problems and Prospects of United Nations Action’ Human Rights Quarterly, (13, 1991) 202-228.
} 
of the early Cold War, something that should be acknowledged by those anti-trafficking activists who call for its revivification today. 
Bibliography

Allain, Jean. 'White Slave Traffic in International Law'. Journal of Trafficking and Human Exploitation 1 (2017), 1-40.

Amos, Jennifer. 'Embracing and Contesting: The Soviet Union and the Universal Declaration of Human Rights, 1948-1958'. In Human Rights in the Twentieth Century, ed. Stefan Ludwig Hoffmann, (Cambridge: Cambridge University Press 2010), 147-165.

Bebel, August. Women and Socialism (New York: Socialist Literature Co., 1910, originally 1879).

Bernstein, Frances. 'Prostitutes and Proletarians: The Soviet Labor Clinic as Revolutionary Laboratory'. In The Human Tradition in Modern Russia, ed. William Husband (Wilmington: Scholarly Resources Inc, 2000).

Betts, Paul. 'Socialism, Social Rights and Human Rights: The Case of East Germany'. Humanity 3(3) (2012), 407-426.

Bowring, Bill. Law, Rights and Ideology: Landmarks in the Destiny of a Great Power (New York: Routledge 2013).

Burke, Roland. Decolonization and the Evolution of International Human Rights, (Philadelphia: University of Pennsylvania Press 2010).

Camiscioli, Elisa. Reproducing the French Race: Immigration, Intimacy and Embodiment in the Early Twentieth Century (Durham: Duke University Press 2006).

Charter of the United Nations (26 June 1945). Accessed via http://www.un.org/en/sections/uncharter/un-charter-full-text/, last accessed 10 July 2018.

Chaumont, Jean-Michel. Le mythe de la traite des blanches. Enquête sur la fabrication d'un fléau (Paris: La Découverte 2009).

Corbin, Alain. Women for Hire. Prostitution and Sexuality in France after 1850 (Cambridge, Massachusetts: Harvard University Press 1990). 
Delierneux, Adolphe. 'The United Nations in the Field of Prevention of Crime and Treatment of Offenders'. In Current approaches to delinquency: Yearbook 1949, ed. National Probation and Parole Association (New York, 1949), 248-258.

Donovan, Brian. White Slave Crusades: Race, Gender and Anti-Vice Activism, 1887-1917

(Urbana-Champaign: University of Illinois Press 2006).

Dullin, Sabine and Etienne Forestier-Peyrat. 'Flexible Sovereignties of the Revolutionary State: Soviet Republics Enter World Politics'. Journal of the History of International Law 19 (2017), 178-199.

El-Ayouty, Yassin. The United Nations and Decolonization: The Role of Afro-Asia (The Hague: Martinus Nijhoff, 1971).

Engels, Friedrich. The Origin of the Family, Private Property and the State (London: Penguin, 2010, originally 1884).

Esakov, Gennady. 'International Criminal Law and Russia: From Nuremberg Passion to The Hague Prejudice'. Europe-Asia Studies $(69.8,2017)$ 1184-1200.

Gaiduk, Ilya. Divided Together: The United States, the Soviet Union, and the United Nations, 1945-1965 (Stanford: Stanford University Press 2013).

García, Magaly Rodríguez. 'La Société des Nations face à la traite des femmes et au travail sexuel à l'échelle mondiale'. Le Mouvement Social 4 (2012), 105-125.

García, Magaly Rodríguez. 'The League of Nations and the Moral Recruitment of Women', International Review of Social History 57 (2012), 97-128, 113-119.

Guy, Donna. Sex and Danger in Buenos Aires: Prostitution, Family and Nation in Argentina (Lincoln: University of Nebraska Press 1991).

Havelková, Barbara. 'Blaming all Women: On Regulation of Prostitution in State Socialist Czechoslovakia', Oxford Legal Studies, 36(1) (2016), 165-191. 
Hetherington, Philippa. 'The Highest Guardian of the Child: International Criminology and the Russian Fight Against Transnational Obscenity, 1885-1925'. Russian History, 43(3-4) (2016), 275-310.

Hirsch, Francine. 'The Soviets at Nuremberg: International Law, Propaganda and the Making of the Postwar Order'. American Historical Review 113(3) (2008), 704-705.

Iandolo, Alessandro. 'Beyond the Shoe: Rethinking Khrushchev at the Fifteenth Session of the United Nations General Assembly. Diplomatic History, 41(1) (2017), 128-154.

Jakobi, Anja P.. Common Goods and Evils: The Formation of Global Crime Governance (New York: Oxford University Press 2013).

Karpets, I. I., Prestupleniia mezhdunarodnogo kharaktera (Moscow: Iuridicheskaia Literature, 1979).

König, Malte. Der Staat als Zuhälter. Die Abschaffung der reglementierten Prostitution in Deutschland, Frankreich und Italien im 20. Jahrhunderts (Berlin/Boston: Walter De Gruyter 2016).

Kollontai, Aleksandra. 'Prostitution and Ways of Fighting it'. In Alix Holt, Selected Writings of Alexandra Kollontai (Allison and Busny, 1977).

Koskenniemi, Martti, Walter Rech, and Manuel Jimenez Fonseca (eds). International Law and Empire. Historical Explorations (Oxford: Oxford University Press 2017).

Laite, Julia Ann. 'The Association for Moral and Social Hygiene: abolitionism and prostitution law in Britain (1915-1959)'. Women's History Review 17 (2) (2008), 207-223.

League of Nations, Report of the special body of experts on traffic in women and children: part one, (Geneva, 1927).

League of Nations, Traffic in Women and Children. Report of the Work of its Fourteenth Session, Geneva, 21 May 1935, C.227.1935.IV, 3. 
Legg, Stephen. “"The Life of Individuals as well as of Nations”: International Law and the League of Nations' Anti-Trafficking Governmentalities'. Leiden Journal of International Law 25 (2012), 647-664.

Lewis, Mark. The Birth of the New Justice: The Internationalization of Crime and Punishment, 1919-1950 (Oxford: Oxford University Press 2014)

Limoncelli, Stephanie. The Politics of Trafficking: The First International Movement to Combat the Sexual Exploitation of Women (Stanford: Stanford University Press 2010).

Lopez-Rey, Manuel. 'First U. N. Congress on the Prevention of Crime and the Treatment of Offenders'. Journal of Criminal Law and Criminology 47(5) (1957), 526-538.

Malksoo, Lauri. Russian Approaches to International Law (Oxford: Oxford University Press, 2015)

Metzger, Barbara. 'Towards an International Human Rights Regime during the Interwar Years. The League of Nations' Combat of Traffic in Women and Children'. In Beyond Sovereignty: Britain, Empire and Transnationalism, c.1880-1950, eds. Kevin Grant, Philippa Levine and Frank Trentmann, (Basingstoke: Palgrave MacMillan 2007), 54-79.

Milhaud, Maurice. 'Social Commission'. World Affairs 110(4) (1947), 245-251.

Ministerstvo Inostrannykh Del SSSR, Sbornik deistvuiushchikh dogovorov, soglashenii i konventsii, zakliuchennykh SSSR s inostrannymi gosudarstvami. Vypusk XVI. (Moscow: Gosudarstvennoe Izadatel'stvo Politicheskoi Literatury, 1957).

Petruccelli, David. 'Pimps, Prostitutes and Policewomen: The Polish Women Police and the International Campaign Against the Traffic in Women and Children between the World Wars'. Contemporary European History 24(3) (2015), 333-350.

Petruccelli, David. 'Banknotes from the Underground: Counterfeiting and the International Order in Interwar Europe'. Journal of Contemporary History 51(3) (2016), 507-530. 
Pheterson, Gail. A Vindication of the Rights of Whores: International Struggle for Prostitutes Rights (Seattle, WA: Seal Press, 1989).

Pliley, Jessica. 'Claims to Protection: The Rise and Fall of Feminist Abolitionism in the League of Nations' Committee on the Traffic in Women and Children, 1919-1936'. Journal of Women's History 22(4) (2010), 90-113.

Radzinowicz Leon. Adventures in Criminology (London: Routledge, 1999).

Reanda, Laura 'Prostitution as a Human Rights Question: Problems and Prospects of United Nations Action'. Human Rights Quarterly 13(2) (1991), 202-228.

Richardson-Little, Ned. 'Between Dictatorship and Dissent: Ideology, Legitimacy and Human Rights in East Germany, 1945-1990,' (PhD Dissertation, University of North Carolina, 2013).

Roberts, Christopher N.J.. The Contentious History of the International Bill of Human Rights, (New York: Cambridge University Press 2014).

Rodríguez García, Magaly. 'The League of Nations and the Moral Recruitment of Women', International Review of Social History 57 (2012), 97-128.

Rodríguez García, Magaly. 'La Société des Nations face à la traite des femmes et au travail sexuel à l'échelle mondiale'. Le Mouvement Social 4 (2012), 105-125.

Schweisfurth, Theodor. 'The Acceptance by the Soviet Union of the Compulsory Jurisdiction of the ICJ for Six Human Rights Conventions'. European Journal of International Law 10 (1990), 110-117.

Simpson, A.W. Brian. Human Rights and the End of Empire: Britain and the Genesis of the European Convention, (Oxford: Oxford University Press 2011), 288-289.

Tambe, Ashwini. 'Climate, Race Science and the Age of Consent in the League of Nations'. Theory, Culture and Society, 28 (2001), 109-130.

United Nations, General Assembly, Ninety-Seventh Plenary Meeting, Second General Assembly, 20 October 1947. 
United Nations, General Assembly, Ninety-Seventh Plenary Meeting, Second General Assembly, 20 October 1947 United Nations General Assembly, Two-Hundred and Sixty-Fourth Plenary Meeting, Fourth General Assembly, A/PV.264.

United Nations, Division of Social Activities, Draft Convention of 1937 for Suppressing the Exploitation of the Prostitution of Others. Memorandum by the Secretary-General, E/574, UN Archives New York, Branch Registries, Volume III - Convention for the Suppression of Traffic in Persons and Obscene Publications, Box S-0441-1163, File 218/03/03.

United Nations, Division of Social Activities, Letter by Dr. Vladimír Houdek, Permanent Delegation of Czechoslovakia to the United Nations, to Trygve Lie, May 6th 1949, UN Archives New York, Volume III, Box S-0441-1163, File 218/04/01.

United Nations, Economic and Social Council, Draft Convention for the Suppression of the Traffic in Persons and of the Exploitation of the Prostitution of Others, E/1072, December 23rd 1948.

United Nations, Economic and Social Council, ECOSOC Resolution 43 (IV) on Social Questions, document E/437, March 29th 1947.

United Nations, Economic and Social Council, Fourth Session. Third Committee, Item 62. Draft Convention for the Suppression of the Traffic in Persons and of the Exploitation of the Prostitution of Others. Ukrainian Soviet Social Republic Amendments to Articles 23, 24 and 27. A/C.3/L.10, 30 September 1949.

United Nations, Economic and Social Council, Observations submitted by Governments and Non-Governmental Organizations with respect to the revision of the 1937 Draft Convention Suppressing the Exploitation of the Prostitution of Others, E/1072/Annex 2, November 18th 1948.

United Nations, Economic and Social Council, Report of the Fourth Session of the Social Commission to the Economic and Social Council, E/1359. E/CN.5/152, 31 May 1949.

United Nations, Economic and Social Council, Social Commission, Fourth Session, Summary Record of the Seventy-Fourth Meeting, May 5th 1949, E/CN.5/Sr 74. 
United Nations, General Assembly, Fourth Session 1949, Official Records, Third Committee (Social, Humanitarian and Cultural), 242nd Meeting, October 5th 1949.

United Nations, General Assembly, Fourth Session 1949, Official Records, 263rd plenary meeting, December 2nd 1949.

United Nations, General Assembly, Fourth Session 1949, Official Records, Sixth Committee, 205th Meeting, November 25th 1949.

United Nations, General Assembly, Fourth Session 1949, Official Records, Third Committee, 242nd Meeting, October 5th 1949.

United Nations, Resolution of the General Assembly, U.N. Doc. A/519. 1947, 32-39. NinetySeventh Plenary Meeting.

Volodin, S, 'Konventsiia o preduprezhdenii prestupleniia genotsida i nakazanii za nego', Sovetskoe Gousdarstvo i Pravo (7: 1954), 125-128.

Walkowitz, Judith R.. City of Dreadful Delight: Narratives of Sexual Danger in Late Victorian London (Chicago: University of Chicago Press 1992).

Walkowitz, Judith R.. Prostitution and Victorian Society. Women, class and the state (Cambridge: Cambridge University Press 1980).

Weiss-Wendt, Anton. The Soviet Union and the Gutting of the UN Genocide Convention (Madison: University of Wisconsin Press 2017).

Zetkin, Clara. Die Arbeiterinnen und Frauenfrage der Gegenwart (Berlin: Berliner BoltsTribüne, 1889). 